DEPRIVING RIGHT-HOLDERS OF

FUNDAMENTAL RIGHTS AND

FREEDOMS TOO EASILY? LOW

VOLUME VEHICLE TECHNICAL

ASSOCIATION INC $V$ BRETT AND THE

ISSUE OF WAIVER UNDER THE NEW

ZEALAND BILL OF RIGHTS ACT 1990

\title{
Rosa Laugesen*
}

\begin{abstract}
In Low Volume Vehicle Technical Association Inc v Brett, the New Zealand Court of Appeal grappled with the rare issue of whether a person can waive their right to freedom of expression under the New Zealand Bill of Rights Act 1990 (NZBORA). The Court, responding in the affirmative, concluded that Mr Brett had waived this right. This article critiques that decision. While the Court was right to find that Mr Brett could waive his right to freedom of expression, it failed to scrutinise the waiver to ensure that this relinquishment of a protected right in fact reflected Mr Brett's free choice. Had the Court considered a different approach to analysing Mr Brett's waiver - at the prima facie breach stage, instead of under 5 of the NZBORA - proper scrutiny would have been achieved. That approach would have ensured that Mr Brett was not so easily deprived of his right.
\end{abstract}

\section{INTRODUCTION}

Writing in the year that the New Zealand Bill of Rights Act 1990 (NZBORA) was passed, DM Paciocco predicted the "inevitable" development of a waiver doctrine under the Act. ${ }^{1}$ Protected rights, in his view, can be, and should be, able to be waived by right-holders. However, he emphasised that the doctrine must be developed to recognise that "persons ought not to be deprived easily of

Submitted for the LLB (Honours) degree, Faculty of Law, Victoria University of Wellington, 2019. I would like to express thanks to my supervisor, Professor Claudia Geiringer, for her guidance and advice.

1 DM Paciocco "The New Zealand Bill of Rights Act 1990: Curial Cures for a Debilitated Bill" [1990] NZ Recent Law Review 353 at 380. 
fundamental rights and freedoms". ${ }^{2}$ In the Court of Appeal's recent decision of Low Volume Vehicle Technical Association Inc v Brett, ${ }^{3}$ a waiver of the right to freedom of expression was considered by a New Zealand court for the second time. ${ }^{4}$ The Court held that the respondent, Mr Brett, could waive his right to freedom of expression, further developing the waiver doctrine in New Zealand as Paciocco had predicted. However, in doing so, the Court failed to heed Paciocco's directive, employing a waiver standard that deprived Mr Brett of his right to freedom of expression too easily.

This article critiques the Court of Appeal's decision in Brett. First, it argues that the Court was correct to find that the right to freedom of expression can be waived: valid exercises of personal autonomy ought to be given effect to by the courts. However, beyond this finding, the Court's analysis of Mr Brett's waiver was unsatisfactory. After assuming that Mr Brett's waiver was best examined under $\mathrm{s} 5$ of the NZBORA, the Court failed to sufficiently scrutinise the waiver. A more fit for purpose approach, ignored by the Court, would have been to consider Mr Brett's waiver when determining whether the right had been breached in the first place. Because this alternative approach is aligned with the theoretical underpinnings of waiver, use of it would have better equipped the Court to give Mr Brett's waiver the "aggressive" scrutiny required. ${ }^{5}$ Ultimately, upon proper interrogation of the alleged waiver under that approach, this article submits that the Court may not have reached the conclusion that $\mathrm{Mr}$ Brett had waived his right to freedom of expression.

\section{THE DISPUTE IN LOW VOLUME VEHICLE TECHNICAL ASSOCIATION INC V BRETT}

\section{A Facts}

The Low Volume Vehicle Technical Association (LVVTA) is an incorporated society that sets modified vehicle standards for low volume vehicles. ${ }^{6}$ Such vehicles are those manufactured in low volumes where the vehicle's construction may affect compliance with vehicle standards or safety requirements. ${ }^{7}$ National certifiers appointed by the New Zealand Transport Agency (NZTA) apply LVVTA standards and issue low volume vehicle certifications. Mr Brett, the respondent in the case, was an approved certifier before his authorisation was revoked by the NZTA. ${ }^{8}$

2 At 381 .

3 Low Volume Vehicle Technical Association Inc v Brett [2019] NZCA 67, [2019] 2 NZLR 808 [Brett (CA)].

4 See Christchurch International Airport Ltd v Christchurch City Council [1997] 1 NZLR 573 (HC).

5 Paciocco, above n 1, at 381.

6 Low Volume Vehicle Technical Association Inc "About Us: What Do We Do" <www.lvvta.org.nz>; and Brett (CA), above n 3, at [1].

7 Brett (CA), above n 3, at [3].

8 Low Volume Vehicle Technical Association Inc v Brett [2017] NZHC 2846, [2018] 2 NZLR 587 [Brett (HC)] at [1]. 
The dispute between Mr Brett and the LVVTA arose when Mr Brett "embarked on a campaign of public criticism" against the LVVTA on his blog. ${ }^{9}$ After the LVVTA threatened legal action, the parties entered into a settlement agreement. The key terms of the agreement were $\mathrm{cl} 4$, whereby the LVVTA agreed not to sue Mr Brett for defamation and cl 5, whereby Mr Brett agreed to remove certain material from his website and refrain from posting particular statements about the LVVTA in the future. ${ }^{10}$

Nevertheless, Mr Brett continued to post offending material after the agreement was reached. The LVVTA then issued proceedings for defamation and for breach of the agreement.

\section{B The New Zealand Bill of Rights Act 1990 Issue}

An issue under the NZBORA arose in regard to the LVVTA's breach of contract claim. If the settlement agreement was in breach of the NZBORA, as Mr Brett argued before the High Court and Court of Appeal, its enforceability by the courts would be limited. The right at issue was Mr Brett's right to freedom of expression, protected by s 14 of the NZBORA. Section 14 states: "[e]veryone has the right to freedom of expression, including the freedom to seek, receive, and impart information and opinions of any kind in any form." Relying on s 14, Mr Brett argued that cl 5 breached his right to freedom of expression by "seeking to prevent any expression of any kind concerning the LVVTA". ${ }^{11}$ The clause at issue stated that Mr Brett agreed to: ${ }^{12}$

(a) immediately remove, and desist from making any further such comments or statements in the future ... that:

(i) are incorrect; or

(ii) are, or may be perceived to be, in any way defamatory toward LVVTA; or

(iii) are, or may be perceived to be, in any way defamatory toward any person(s) employed by and/or associated with LVVTA;

and

(b) immediately remove, and desist from making any further such ... statements in the future ... that are not accompanied by clear and relevant documented evidence that supports the ... statements being made; and

$9 \quad$ Brett (CA), above n 3, at [1]

10 Brett (HC), above n 8, at [19].

11 At [93].

12 Low Volume Vehicle Technical Association Inc and John Brett Settlement Agreement (5 June 2014) [Settlement Agreement], cl 5, as quoted in Brett (CA), above n 3, at [11] (emphasis added). 
(d) prior to publishing any ... statements about LVVTA ... provide an LVVTA staff-member ... with the opportunity to review the intended ... statement(s), and he will either:

(i) refrain from making the ... statement if the LVVTA staff member can demonstrate that the ... statement is incorrect; or

(ii) in the case that the ... statement is correct, allow the LVVTA staff member's written response to be provided immediately after the ... statement ...

The High Court and Court of Appeal accepted that the NZBORA applied to the LVVTA's "act" of entering into the settlement agreement. ${ }^{13}$ This met the s $3(\mathrm{~b})$ definition of an act done "by any person or body in the performance of any public function, power, or duty conferred or imposed on that person or body by or pursuant to law". The LVVTA was accordingly held to be a "s 3 body", ${ }^{14}$ the consequence being that the agreement had to comply with the NZBORA in order to be enforceable. ${ }^{15}$

However, even if the LVVTA's act of entering into the agreement had limited Mr Brett's right to freedom of expression, it would not automatically follow that it breached the NZBORA. Section 5 of the Act operates as a justification mechanism whereby s 3 bodies can establish that a prima facie interference with a given right is "justified". For the benchmark to be surpassed, the limit must be (a) demonstrably justified in a free and democratic society; and (b) prescribed by law. ${ }^{16}$ Only an unjustified limitation on Mr Brett's right to freedom of expression could render the contract, or parts of it, unenforceable.

$\mathrm{Mr}$ Brett argued that $\mathrm{cl} 5$ constituted an unjustified limitation on his right to freedom of expression and as a result, should be rendered unenforceable for inconsistency with the NZBORA. ${ }^{17}$ However, this argument gave rise to a separate issue in both courts. Had Mr Brett nevertheless waived his right to freedom of expression by agreeing to this clause? What did this mean for Mr Brett's claim that his right had been breached by the LVVTA?

\section{HIGH COURT DECISION}

In the High Court, Palmer J considered the issue of waiver in one paragraph. ${ }^{18}$ His Honour raised the matter after already concluding that parts of cl 5 (sub-cls (a)(i), (d)(i) and (d)(ii)) should be voided

13 Brett (HC), above n 8, at [97]; and Brett (CA), above n 3, at [27]-[29]

14 Paul Rishworth "Who does the Bill of Rights apply to?" in Essays on the New Zealand Bill of Rights Act 1990 (Legal Research Foundation, Auckland, 1992) 19 at 24.

15 Brett (HC), above n 8, at [107]; and Brett (CA), above n 3, at [33].

16 New Zealand Bill of Rights Act 1990 [NZBORA], s 5.

17 Brett (CA), above n 3, at [2(a)] and [22].

18 Brett (HC), above n 8, at [106]. 
for inconsistency with the NZBORA. ${ }^{19}$ Pointing out that the issue of waiver was not argued by either counsel before the Court, Palmer J hypothesised that perhaps "Mr Brett agreed to these restrictions so he was limiting his own rights". ${ }^{20}$

His Honour first entertained the possibility that Mr Brett could waive his right to freedom of expression. But even assuming this right could be waived, Palmer $\mathbf{J}$ expressed hesitation about whether Mr Brett's waiver was valid. His Honour emphasised that, even if Mr Brett had agreed to cl 5 , "he did so under the threat of legal action and without legal advice". ${ }^{21}$ Notwithstanding this, his Honour did not appear convinced that this right could be waived. He relied on the sole authority of Rommelfanger $v$ Federal Republic of Germany in support of this belief, in which the European Commission of Human Rights rejected the argument that one's right to freedom of expression could be waived through an employment contract. ${ }^{22}$

Ultimately, Palmer J concluded that "[i]f it were necessary to determine", he would have found that the Rommelfanger position applied: Mr Brett could not waive his right to freedom of expression through the agreement. ${ }^{23}$ It is unclear why his Honour did not believe that the issue was "necessary to determine". The most likely explanation, is that Palmer $\mathbf{J}$ simply raised this argument as an afterthought. Indeed, his Honour had already reached a position on the NZBORA issue, finding that parts of $\mathrm{cl} 5$ were void. As the argument was not advanced by either counsel, Palmer J may have determined that merely raising the possibility of waiver was sufficient, as opposed to reaching a definitive finding on it.

\section{COURT OF APPEAL DECISION}

Palmer $\mathrm{J}$ in the High Court considered that the issue of waiver was unnecessary to determine. The Court of Appeal squarely addressed it. Importantly, the Court found that the right to freedom of expression can be waived through contract. Unlike Palmer J, who expressed hesitation at this notion, the Court of Appeal readily accepted it, making three arguments in support of this conclusion.

First, the Court noted that the practice of individuals self-limiting their rights in private law is ubiquitous. ${ }^{24}$ The Court used the example of A, who commits a tort against B. If A and B enter into a settlement agreement to avoid litigation, $\mathrm{B}$ relinquishes their right in tort and replaces it with a new right in contract. The Court argued that, not only is this practice common, but it is also in the public

\footnotetext{
19 At [102]-[105] and [108].

20 At [106].

21 At [106].

22 Rommelfanger $v$ Federal Republic of Germany (1989) 62 DR 151.

23 Brett (HC), above n 8, at [106].

24 Brett (CA), above n 3, at [31].
} 
interest. In its view, when A and B elect to settle - thereby waiving any right to a remedy - civil society benefits from this avoidance of potentially "protracted and destructive" litigation. ${ }^{25}$

Secondly, the Court found that waivers in a NZBORA context are a corollary of the fact that rights are not absolute ${ }^{26}$ rights can be permissibly limited, provided that the limits are justified under $\mathrm{s} 5 .^{27}$

Finally, the Court noted that "protected rights may be lawfully qualified ... where the actor perceives a benefit may be obtained from an exchange of rights". ${ }^{28}$ The Court gave the example of the NZBORA s 23(4) right not to make a statement on arrest, noting that many people, when arrested, prefer to waive this right and give an account of their actions, as opposed to remaining silent. Extracting further examples from Tipping J's judgment in Christchurch International Airport Ltd $v$ Christchurch City Council, ${ }^{29}$ the only other New Zealand case to consider a s 14 waiver, the Court noted that right-holders frequently surrender the s 23(1)(b) right to legal advice and the s 14 right to freedom of expression because it is advantageous to do so. ${ }^{30}$

While accepting that the right to freedom of expression can be waived through contract, the Court of Appeal emphasised that any right-limiting act must be justified under s 5 of the NZBORA. ${ }^{31}$ This requires that the limitation is prescribed by law and can be demonstrably justified in a free and democratic society. The Court noted that the beneficial worth of "upholding compromises to litigation" is important to this inquiry, as well as whether consent was obtained by "unconscionable means". 32

Importantly, the Court found that a contractual abrogation is prescribed by law. This hurdle requires that the right-limiting act or omission is not only authorised by law, but that this law is "adequately accessible to the public" and "formulated with sufficient precision" as to guide citizens' conduct. ${ }^{33}$ While noting that this particular application of the prescribed by law requirement had not

25 At [31].

26 At [34].

27 NZBORA, s 5.

28 Brett (CA), above n 3, at [35].

29 Christchurch International Airport Ltd, above n 4, at 583 per Tipping J.

$30 \quad \operatorname{Brett}(\mathrm{CA})$, above $\mathrm{n} 3$, at [35]

31 At [38].

32 At [38].

33 Andrew Butler and Petra Butler The New Zealand Bill of Rights Act: A Commentary (2nd ed, LexisNexis, Wellington, 2015) at [6.12.2]. See also Grant Huscroft "Reasonable limitations on rights and freedoms" in The Bill of Rights Act - getting the basics right (New Zealand Law Society seminar, 2001) 59 at 61. 
been "directly considered by New Zealand courts before", 34 the Court found that a contractual abrogation is prescribed by law to the extent that the agreement is otherwise enforceable at common law. ${ }^{35}$ In reaching this conclusion, the Court appeared to be persuaded by its earlier finding that one should be able to waive one's right to freedom of expression. It stated that to find otherwise - that a contractual abrogation falls short of this s 5 requirement, rendering it unenforceable - would be "perverse". 36 "This is the kind of right which people should ... be allowed to surrender 'for what they see as their own advantage'", the Court emphasised. ${ }^{37}$

Clause 5 was also held to be demonstrably justified, clearing the remaining hurdle of $\mathrm{s} 5$. The Court of Appeal disagreed with Palmer J's finding that sub-cls (a)(i), (d)(i) and (d)(ii) constituted an unjustified limitation on Mr Brett's right to freedom of expression. ${ }^{38}$ To the contrary, the Court found that cl 5 was lawful and the agreement was valid in its entirety. ${ }^{39}$ Relying on observations made by Tipping $\mathrm{J}$ in Christchurch International Airport Ltd, ${ }^{40}$ the Court said that where the "limitation is entered into voluntarily for the surrendering party's perceived advantage, it is difficult to see why such a limitation ... ought not to be effective". ${ }^{41}$

Finally, the Court concluded that "had it been necessary to do so", it would not have found that parts of cl 5 lacked rational justification, as Palmer $\mathrm{J}$ had. ${ }^{42}$ In the Court's view, the sub-cls at issue constituted a "modest" concession on Mr Brett's right to freedom of expression. ${ }^{43}$ Moreover, the Court noted that Mr Brett had elected to enter into the settlement agreement, rather than submit to judicial determination where his legal position was "perilous". ${ }^{44}$ Finally, the Court noted that Mr Brett had voluntarily agreed to these obligations. ${ }^{45}$

34 Brett (CA), above n 3, at [37] and n 48

35 At [37].

36 At [37].

37 Brett (CA), above n 3, at [37] (emphasis added), quoting Christchurch International Airport Ltd, above n 4, at 583 .

38 See Brett (HC), above n 8, at [102]-[105].

39 Brett (CA), above n 3, at [40].

40 Christchurch International Airport Ltd, above n 4, at 583.

41 Brett (CA), above n 3, at [40].

42 At [41].

43 At [41(a) and (c)].

44 At [41].

45 At [41(c)]. 


\section{CRITIQUE OF THE COURT OF APPEAL DECISION}

\section{A Correct Conclusion That the Right Can Be Waived}

The Court of Appeal was right to conclude that one should be able to contract out of one's right to freedom of expression; this was a welcome development in the waiver doctrine. The reasons given by the Court itself in support of this finding were, this article suggests, entirely correct. However, a further argument, not directly addressed by the Court, can also be made in support of the availability of waiver: that by recognising waivers, the courts give effect to the value of autonomy that underpins a liberal democracy.

First, the Court was correct to suggest that recognising waivers gives effect to the "beneficial worth in a civil society of upholding compromises to litigation". ${ }^{46}$ At a societal level, settlement agreements serve the interests of the administration of justice by freeing court resources for other cases. ${ }^{47}$ Moreover, at an individual level, these agreements also serve the interests of private litigants. ${ }^{48}$ As Lord Bingham said: ${ }^{49}$

The law loves a compromise. ... A party who settles foregoes the chance of total victory, but avoids the anxiety, risk, uncertainty and expenditure of time which is inherent in almost any contested action, and escapes the danger of total defeat.

This was indeed the case for Mr Brett who, as the Court observed, elected to enter into a settlement agreement rather than "submit to judicial determination". ${ }^{50}$ Brett, whose "legal position was perilous" and whose "pocket was at significant risk" chose not to defend his actions "with all the risk that brought with it", the Court said. ${ }^{51}$

If right-limiting settlement agreements are rendered unenforceable by the courts because they breach the NZBORA, this undermines the benefit in preserving compromises to litigation. By recognising waivers, however, a finding of unenforceability is less likely. This promotes the public interest served by maintaining compromises to litigation.

46 At [38].

47 Mionis v Democratic Press SA [2017] EWCA Civ 1194, [2018] QB 662 at [89]; and Judith A McMorrow "Who Owns Rights: Waiving and Settling Private Rights of Action" (1989) 34 Vill L Rev 429 at 459.

48 Mionis, above n 47, at [89].

49 David Foskett The Law and Practice of Compromise (4th ed, Thomson Reuters, Toronto, 1996) at xi, as quoted in Mionis, above n 47, at [88].

50 Brett (CA), above n 3, at [32].

51 At [41]. 
The Court was also correct to suggest that people ought to be able to surrender their right "for what they see as their own advantage". ${ }^{2}$ The Court noted that Tipping J in Christchurch International Airport Ltd argued this, saying that: ${ }^{53}$

There is nothing inherently inimical in surrendering ... one's freedom of expression. Commercial documents and settlements of litigation frequently contain clauses whereby each party ... surrenders his/her freedom of expression. They do so because the parties regard it as commercially advantageous ...

to do so.

The Court of Appeal and Tipping J both made a common sense argument: why should the courts prevent an individual from waiving their right to freedom of expression if it is to their own advantage? Indeed, in Brett, the Court highlighted the "manifest" benefits of Mr Brett electing to agree to the right-limiting terms, rather than face costly litigation. ${ }^{54}$ As Jørgan Aall puts it, "[i]n a liberal democracy ... it seems strange if the individual were to be barred from utilising such advantages stemming from his human rights." 55

Therefore, as can be seen, the Court put forward a convincing case for recognising Mr Brett's waiver. However, it missed perhaps the most salient argument in favour of allowing right-holders to waive their right to freedom of expression: autonomy. Autonomy is a value that underpins liberal society. In essence, autonomy is about individual choice. ${ }^{56}$ At its extreme, liberal theory argues that the government ought to respect all exercises of autonomy so long as they are not exercised to infringe upon the autonomy of others. ${ }^{57}$

Scholars have made a number of connections between autonomy and human rights theory. HLA Hart submitted that there is a fundamental connection between rights and agency. ${ }^{58}$ In his view, all rights presuppose the right to liberty and the capacity for personal choice. ${ }^{59}$ As a corollary, it is up to

52 Christchurch International Airport Ltd, above n 4, at 585, as quoted in Brett (CA), above n 3, at [37].

53 Christchurch International Airport Ltd, above n 4, at 585, as quoted in Brett (CA), above n 3, at [35] (emphasis added).

54 Brett (CA), above n 3, at [40]-[41].

55 Jørgen Aall Waiver of Human Rights: Setting the Scene (Part I/III) (2010) 28 NJHR 300 at 302.

56 Alan Young "'Not Waving But Drowning': A Look at Waiver and Collective Constitutional Rights in the Criminal Process" (1989) 53 Sask L Rev 47 at 51.

57 Jessica Wilen Berg "Understanding Waiver" (2003) 40 Hous LR 281 at 289. See also John Stuart Mill On Liberty (2nd ed, Ticknor and Fields, Boston, 1863) at 48.

58 HLA Hart "Are There Any Natural Rights?" (1955) 64 The Philosophical Review 175.

59 Aall, above n 55, at 302. 
the individual to determine how and whether to exercise their rights. ${ }^{60}$ Similarly, Immanuel Kant contended that the purpose of rights is to allow individuals to freely pursue their own ends. ${ }^{61}$

If autonomy presupposes that individuals can choose how to exercise their rights, this must include the choice to relinquish or waive that right. ${ }^{62}$ The theoretical groundings of waiver are therefore deeply rooted in autonomy. Tipping $\mathrm{J}$ in Christchurch International Airport Ltd noted the connection between autonomy and waiver when he stated: ${ }^{63}$

The Bill of Rights gives individual citizens particular rights and freedoms. It would seem somewhat contradictory to say that such rights and freedoms may not be given up for what the person concerned regards as valid reasons. The concept of freedom presupposes not only that you are free to enforce your right but that you are free not to enforce it and to waive it, if you choose to do so.

In order to respect a right-holder's autonomy, the courts should therefore recognise the exercise of autonomy manifested when a right-holder decides to waive a given right. ${ }^{64}$

Nevertheless, scholars of Alan Young's persuasion reject the notion that individuals should be able to choose whether they receive the benefit of protected rights. ${ }^{65}$ Young argues that a rightholder's decision to consent to an interference with their rights should not allow the state to abandon its constitutional boundaries. Waivers, he argues, harm other right-holders who have an interest in seeing the state stay within the constitutional scheme. ${ }^{66}$ Rights are not personally possessed by rightholders, able to be commodified, but rather collective interests of citizens as a whole. ${ }^{67}$ Loukis Loucaides agrees, noting that: ${ }^{68}$

60 Alex Gourevitch "Are Human Rights Liberal?" (2009) 8 Journal of Human Rights 301 at 321

61 Immanuel Kant "The Metaphysics of Morals" in Political Writings (2nd ed, Hans Reiss (ed) and HB Nisbet (translator), Cambridge University Press, Cambridge, 1970) 131 at 133; and Gourevitch, above n 60, at 321.

62 Berg, above n 57, at 289. See also Christopher Harker "Consent Searches and Section 21 of the New Zealand Bill of Rights Act 1990" (2011) 9 NZJPIL 137 at 161; Aall, above n 55, at 301; and Peter Hogg (ed) Constitutional Law of Canada (looseleaf ed, Thomson Reuters) at [37.3(b)].

63 Christchurch International Airport Ltd, above n 4, at 583 (emphasis added).

64 Berg, above n 57, at 289.

65 See Young, above n 56, at 102; Loukis G Loucaides "Questions of Fair Trial under the European Convention on Human Rights" (2003) 3 HRL Rev 27; and Gillian S Morris "Fundamental Rights: Exclusion by Agreement?" (2001) 30 ILJ 49.

66 See Young, above n 56, at 102.

67 At 102. See also Morris, above n 65, at 55.

68 Loucaides, above n 65, at 48. 
... human rights are conferred on the individual in the public interest in order to effectuate a policy of protecting him from the omnipotence of the State ... They are not private personal rights that can be negotiated, compromised [or] waived $\ldots$ by the individual.

The problem with Young and Loucaides' argument is twofold. First, while there is a public interest in seeing the state recognise rights generally, for example by legislating for and enforcing a bill of rights instrument, it does not follow that all rights are collective in nature. ${ }^{69}$ The better view is that every individual is endowed with a set of basic human rights which are inalienable to the extent that the right-holder wishes to hold onto them. However, if a right-holder decides to waive a right in selfinterest, this is a personal choice that ought to be respected by the courts. After all, it is arguable that waiving one's right to freedom of expression affects no-one directly beyond the right-holder; the only impact is on that individual's right. ${ }^{70}$ If this is the case, why should that individual be prohibited from foregoing the benefit of the right? In the words of leading constitutional scholar Peter Hogg, the right is for the benefit of the individual who chooses to waive it. ${ }^{71}$

Moreover, the argument that the right to freedom of expression should not be waived because it is inalienable is hypocritical. A key rationale underpinning this right is the notion of human selffulfilment: that expression holds intrinsic value in and of itself. By seeking, receiving and imparting information and opinions, this helps right-holders to develop an understanding of who they are and to reach their full potential. ${ }^{72}$ This rationale is predicated on autonomy - on an individual's ability to achieve self-actualisation through any kind of expression, "however unpopular, distasteful or contrary to the mainstream" the content of that expression is. ${ }^{73}$ If we regard the right to freedom of expression as sacred and, by implication, the concept of autonomy on which its self-fulfilment rationale depends, similar exercises of autonomy should also be regarded as sacred. The personal autonomy promoted by expression is not that distinct from the autonomy exercised to waive that same right. Hogg is right to point out that "most rights are intended to protect the ... autonomy of the individual, and the practice of waiver is consistent with that purpose".${ }^{74}$ This article submits that this is the better view.

69 See Hogg, above n 62, at [37.3(b)].

70 Compare Morris, above n 65, at 55.

71 See Hogg, above n 62, at [37.3(b)]

72 Butler and Butler, above n 33, at [13.6.4]; and $R v$ Sharpe [2001] 1 SCR 45 at [141] per L'Heureux-Dubé, Gonthier and Bastarache JJ.

73 Irwin Toy Ltd v Québec (Attorney General) [1989] 1 SCR 927 at [41], as quoted in $R$ v Sharpe, above n 72, at [145]. See also Susan Easton "Autonomy and the Free Speech Principle" (1995) 12 J Applied Phil 27.

74 Hogg, above n 62, at [37.3(b)]. See also Harker, above n 62, at 161 


\section{B Approach to Waiver Was Not Fit for Purpose}

The Court was right to find that one should be able to waive one's right to freedom of expression, but its treatment of waiver beyond this conclusion was inadequate. After assuming that Mr Brett's waiver should be considered under s 5 of the NZBORA, the Court then failed to properly apply a s 5 analysis, inhibiting its ability to rigorously scrutinise the waiver. There are arguments in support of a s 5-centred analysis, or the "ad hoc balancing" approach as labelled by its proponents. However, this article ultimately concludes that when it comes to considering a waiver, a s 5 approach is not fit for purpose.

\section{The s 5 approach}

Brett appears to be the first case to consider a waiver of the right to freedom of expression in over 20 years. ${ }^{75}$ With this, the Court of Appeal was given a rare opportunity to clarify how s 14 waivers fit into the NZBORA framework.

The basic framework for considering a claim under the NZBORA is twofold. First, the rightholder must show that there has been a "prima facie" limitation of a protected right. ${ }^{76}$ This involves a determination of the scope of the right. If a prima facie breach is established, the second step is to ask whether this limitation is justified under s $5 .^{77}$ The onus of establishing this shifts to the party seeking to limit the right - the s 3 body. ${ }^{78}$ Only if the limit cannot be demonstrably justified will there be a breach of the NZBORA.

An important issue is how waivers interact with this framework. If evidence comes before the court that a right-holder consented to the interference at issue, how should this be taken into account? What impact does a right-holder's consent have on their NZBORA claim against the s 3 body?

There are two different approaches that can be taken to waivers, each interacting with the NZBORA framework differently. The first approach considers waiver at the prima facie breach stage. When there is evidence of waiver before the court, a burden is placed on the s 3 body to establish that the right-holder's waiver was valid. ${ }^{79}$ To be valid, the court must be satisfied that the waiver was

75 See Christchurch International Airport Ltd, above n 4

76 Paul Rishworth "The New Zealand Bill of Rights Act 1990: The First Fifteen Months" in Essays on the New Zealand Bill of Rights Act 1990 (Legal Research Foundation, Auckland, 1992) 7 at 19; and Butler and Butler, above $\mathrm{n} 33$, at [6.6.7].

77 Butler and Butler, above n 33, at [6.6.6]

78 At [6.6.7]. See also Paul Rishworth "How to Interpret and Apply the Bill of Rights" in The Bill of Rights Act - getting the basics right (New Zealand Law Society seminar, 2001) 12.

79 Butler and Butler, above n 33, at [20.11.35] 
informed, unequivocal and voluntary. ${ }^{80}$ If the standard is met - and there has been a valid waiver there is no interference with the right ${ }^{81}$ and the right-holder's claim under the NZBORA automatically fails. This approach reflects that taken by the courts in respect of waivers of certain procedural rights contained in the NZBORA, for example the right to consult and instruct a lawyer in s 23(1)(b) $)^{82}$ and the right to refrain from making a statement in s 23(4). ${ }^{83}$

By comparison, the second approach considers waiver at the s 5 stage. Even if there is evidence of waiver before the court, there will still be a prima facie interference with the right which must be justified under $\mathrm{s} 5$. Along with other matters of justification relevant to $\mathrm{s} 5$, the waiver is weighed up in determining the reasonableness of the interference. ${ }^{84}$

Both approaches recognise that waivers must be subjected to scrutiny. After all, waivers assert that a right-holder has relinquished a given right, hindering their ability to rely on its protection. ${ }^{85}$ This may persuade a court to find that the s 3 body has limited the right justifiably (under the s 5 approach), or perhaps not at all (under the prima facie breach approach). Section 3 bodies should not be able to abandon their constitutional commitments to respecting rights unless and until a court is satisfied that the waiver does in fact reflect the right-holder's free choice. ${ }^{86}$ Whereas the prima facie breach approach scrutinises the waiver by applying the waiver standard, the s 5 approach achieves scrutiny by undertaking a broader reasonableness assessment of the limitation at issue. These safeguards give effect to Paciocco's notion that "persons ought not to be deprived easily of fundamental rights and freedoms". ${ }^{87}$

The Court of Appeal adopted the s 5 approach. ${ }^{88}$ It did not consider the prima facie breach approach, nor did it provide any justification for why it elected its favoured approach. Instead, the Court appeared to assume that the two-stage methodology was fit for purpose for a case involving waiver.

80 Lisiate $v$ R [2011] NZCA 170 at [15]; and Police v Kohler [1993] 3 NZLR 129 (CA) at 133. See also Hogg, above $\mathrm{n} 62$, at [37.3(a)].

81 Aall, above n 55, at 312; and Hogg, above n 62, at [37.3(a)].

82 See Police v Kohler, above n 80. For further discussion see Butler and Butler, above n 33, at [20.7.60].

83 See Lisiate v $R$, above $\mathrm{n}$ 80. For further discussion see Butler and Butler, above n 33, at [20.11.35].

84 Cropp v Judicial Committee [2008] NZSC 46, [2008] 3 NZLR 774 at [21].

85 Johnson v Zerbst 304 US 458 (1938) at 464. See also Young, above n 56, at 50.

86 See Michael E Tigar "Foreword: Waiver of Constitutional Rights - Disquiet in the Citadel" (1970) 84 Harv L Rev 1 at 8 .

87 Paciocco, above n 1, at 381.

88 Brett (CA), above n 3, at [38]. The Court stated at [38]: " ... for a limitation by abrogation to be lawful, it must also pass muster as being demonstrably justifiable in a free and democratic society". 


\section{Support for the s 5 approach}

While the Court of Appeal did not provide reasons for adopting a s 5 approach to waiver, this approach accords with that taken by the New Zealand Supreme Court in Cropp $v$ Judicial Committee. ${ }^{89}$ In that case, an issue arose about the effect of a right-holder's consent to a "search" within the meaning of s 21 of the NZBORA: the right to be secure against unreasonable search or seizure. The Court found that consent could not put a particular search outside the protection of s $21 .^{90}$ Instead, the Court believed that the fact of consent, and the quality of consent, are both matters relevant to assessing the reasonableness of a search..$^{91}$

It should be noted that the approach in Cropp is analogous, but not identical, to the Court's s 5 approach in Brett. Section 21 of the NZBORA, the right to be free from "unreasonable search or seizure", is expressed in such a way that matters of justification are integral to its definition. ${ }^{92}$ Accordingly, the reasonableness assessment is undertaken at the definitional stage, not under s 5 . Regardless, the Supreme Court's approach in Cropp envisaged waiver as an important matter going to whether the search was reasonable, as opposed to whether there was a search or an interference in the first place. This is consistent with the Court's s 5 approach in Brett.

In Cropp, the Supreme Court was reluctant to allow consent to put particular conduct outside the protection of the NZBORA. In the Court's view, all limitations on protected rights, whether consented to or not, ought to be scrutinised for justification. This concurs with the "ad hoc balancing" approach advocated by some scholars ${ }^{93}$ and judges. ${ }^{94}$ As opposed to the "definitional balancing" approach which involves reading limitations into rights at the definitional stage (the first stage of the NZBORA framework), the ad hoc balancing approach defines rights as broadly as possible. In doing so, the courts take an expansive approach to finding prima facie interferences with rights, thereby ensuring all "interferences" are scrutinised under s 5 (the second stage of the NZBORA framework). The Court of Appeal's determination that Mr Brett's right to freedom of expression had been interfered with, despite evidence of waiver, accords with this two-stage, s 5-centred approach.

89 Cropp, above n 84 .

90 At [21].

91 At [21].

92 Section 21 (emphasis added). See Rishworth "How to Interpret and Apply the Bill of Rights", above n 78, at 15.

93 See for example Rishworth "How to Interpret and Apply the Bill of Rights", above n 78, at 14; Rishworth "The New Zealand Bill of Rights Act 1990: The First Fifteen Months", above n 76, at 19; and Butler and Butler, above n 33 , at [6.6.6].

94 See for example Quilter v Attorney-General [1998] 1 NZLR 523 (CA) per Tipping J; and Ministry of Health $v$ Atkinson [2012] NZCA 184, [2012] 3 NZLR 456. 
Andrew Butler and Petra Butler make three arguments in favour of the two-stage ad hoc balancing approach. ${ }^{95}$ First, it is consistent with a purposive reading of the NZBORA that locates $\mathrm{s} 5$ in a separate Part from the protected rights and freedoms. ${ }^{96}$ Secondly, it better allocates the burden of proof, with the onus shifting to the s 3 body at the second stage to demonstrate that the limitation is justified under s $5 .{ }^{97}$ Thirdly, and most importantly, it "ensures clearer, more transparent analysis". 98 By dealing with matters of justification under s 5, each interference with a right is "scrutinised with an eye to the detail of the particular right in issue, the scheme impugned and the context disclosed by the particular case". 99

The preferred method for determining whether the standard set by s 5 has been passed - that a limitation is "reasonable" and can be "demonstrably justified in a free and democratic society" 100 - is to apply a modified version of the $R v$ Oakes test, ${ }^{101}$ a framework established by the Canadian Supreme Court. The Oakes test emphasises rationality and proportionality between the purpose of the right-limiting act or omission and the limitation itself. ${ }^{102}$ Tipping $\mathrm{J}$ formulated the test in Hansen $v R$ as: 103

(a) does the limiting measure serve a purpose sufficiently important to justify curtailment of the right or freedom?

(b) (i) is the limiting measure rationally connected with its purpose?

(ii) does the limiting measure impair the right or freedom no more than is reasonably necessary for sufficient achievement of its purpose?

(iii) is the limit in due proportion to the importance of the objective?

Ultimately, proponents of the two-stage approach argue that it allows for the "[v]ital questions of justification" to be explored in NZBORA claims. ${ }^{104}$ Perhaps, then, the Court of Appeal believed that considering Mr Brett's waiver under s 5 would give it maximum rigour and scrutiny.

95 Butler and Butler, above n 33, at [6.6.6]-[6.6.10].

96 At [6.6.6].

97 At [6.6.7].

98 At [6.6.8].

99 At [6.6.8].

100 NZBORA, s 5.

$101 R v$ Oakes [1986] 1 SCR 103.

102 Huscroft, above n 33, at 65.

103 Hansen v R [2007] NZSC 7, [2007] 3 NZLR 1 at [104].

104 Rishworth "How to Interpret and Apply the Bill of Rights", above n 78, at 13. 


\section{The Court's misapplication of the s 5 approach}

If the Court of Appeal's intention behind employing a two-stage approach - or a "s 5 approach" was to give the waiver maximum scrutiny, it was an intention on which it completely failed to deliver. In practice, the Court misapplied s 5, failing to subject Mr Brett's waiver to any rigour. This demonstrated that when there is evidence of waiver before a court, a s 5 approach is not fit for purpose.

The overarching problem with the Court's analysis is that when it came to the point, it failed to meaningfully engage with $\mathrm{s} 5$. Correctly applied, s 5 requires the court to determine that first, the limitation is prescribed by law and secondly, that it is "reasonable" and "demonstrably justified in a free and democratic society". As discussed earlier, courts often elect to adopt the Oakes test to determine whether the second hurdle of s 5 has been met. For a case like Brett, it would be expected that matters such as the quality of Mr Brett's consent and the public interest in upholding settlement agreements would be scrutinised and balanced under Oakes in order to reach a finding of whether the limitation was justified. ${ }^{105}$ The Court itself noted that these contextual factors would be relevant to determining whether the contractual abrogation was lawful. ${ }^{106}$ Only if the limitation passes the requirements of s $5,{ }^{107}$ the Court emphasised, can a determination be reached that it was justified. ${ }^{108}$ However despite that theoretical acknowledgement of the centrality of s 5, when it came to it, the Court's approach barely resembled a conventional s 5 inquiry; the Court concluded that the limitation was prescribed by law, but it neglected to engage, more than in passing, with whether it was demonstrably justified.

In a short paragraph, the Court outlined the crux of its analysis under s 5:109

The limitations here were entered voluntarily by Mr Brett. The benefits to him were manifest. Differing from the [High Court] Judge, we conclude that the contractual abrogation of rights was lawful, and the agreement was valid in its entirety.

Thus, given Mr Brett's waiver was effective, ${ }^{110}$ the Court concluded that the limitation on his right was lawful and the agreement was valid. ${ }^{111}$ Contrary to the thrust of $\mathrm{s} 5$, the Court's finding of

105 Butler and Butler, above n 33, at [6.6.8]. See also Rishworth "How to Interpret and Apply the Bill of Rights", above $\mathrm{n} 78$, at 13

106 Brett (CA), above n 3, at [38].

107 Butler and Butler, above n 33, at [6.3.1]

108 Not only is this self-evident in the wording of s 5, but the Court also emphasised this: see Brett (CA), above $\mathrm{n} 3$, at [38].

109 At [40].

110 At $[40]$.

111 At [40] 
lawfulness was not based on an overt analysis that the limitation was justified, rather that Mr Brett's waiver was effective. Here, the Court abandoned its own s 5 approach, failing to discuss matters of reasonableness, justification or proportionality, and neglecting to apply Oakes, the preferred test for whether a limitation is justified. The contextual matters that the Court itself said would be relevant under s 5 - such as the quality of Mr Brett's consent and the public interest attached to upholding settlement agreements - were left untouched. ${ }^{112}$ Ultimately, instead of the "clear" and "transparent" analysis promised by s 5 proponents, ${ }^{113}$ the Court concluded that the limitation on Mr Brett's right to freedom of expression was lawful without the s 5 assessment to back it up.

Having just concluded that the limitation on Mr Brett's right was lawful, the Court of Appeal then stated that, "had it been necessary to do so", it would not have concluded, as Palmer J had, that parts of $\mathrm{cl} 5$ lacked rational justification. ${ }^{114}$ This assertion is baffling. The Court just purported to subject the settlement agreement - and its alleged limitation contained therein - to s 5. Indeed, the Court had said a few paragraphs before that "for a limitation by abrogation to be lawful, it must also pass muster as being demonstrably justified in a free and democratic society". ${ }^{115}$ In order to be consistent with its own stated principles, the Court's finding that the limitation was lawful, therefore, must have been based on a finding that it was justified, even if this was not overt. Why then would the Court say that "had it been necessary to do so" it would not have concluded that parts of cl 5 lack justification.

Then apparently applying s 5 for the second time, the Court gave reasons why the limitations on $\mathrm{Mr}$ Brett's right in cl 5 were justified. However, this time its analysis was stated in the hypothetical. Given that the Court had already reached a conclusion that the agreement was lawful, this additional consideration of $\mathrm{s} 5$ is under the proviso of "had it been necessary to do so". ${ }^{116}$ In this hypothetical analysis, the Court noted that the impact on Mr Brett's right to freedom of expression was "modest", that the LVVTA's response was "proportionate" and that Mr Brett had voluntarily assumed the obligations. ${ }^{117}$ Accordingly, "had it been necessary", the Court would have concluded that the limitations on Mr Brett's right contained in cl 5 were justified. ${ }^{118}$ Not only is it strange that the Court elected to apply s 5 twice, but even more bewildering is that its second analysis was far more akin to what would be expected from an assessment under s 5, with consideration given to notions of

112 At [38].

113 Butler and Butler, above n 33, at [6.6.8].

114 Brett (CA), above n 3, at [41].

115 At [38].

116 At [41].

117 At [41(c)].

118 At [41]. 
proportionality, justification and reasonableness. Far less rigorous and adequate was the Court's earlier reasoning for why the limitation of Mr Brett's right was lawful and the agreement was valid.

The Court's analysis is troubling. After first asserting that a limitation must pass muster under s 5 to be lawful, ${ }^{119}$ the Court failed to follow its own directive to properly apply s 5. Only under the proviso "had it been necessary to do so", does the Court properly engage with it. Not only did this demonstrate poor judicial reasoning but, more importantly, it led to a gap in the Court's analysis. In addition to neglecting to subject the waiver to scrutiny under s 5 , the Court did not subject it to the waiver standard either. Indeed, the Court's finding that Mr Brett's waiver was effective is based on unsatisfactory reasoning that it was entered into "voluntarily" and for his "perceived advantage". ${ }^{120}$ There is no application of the "informed, unequivocal and voluntary" criteria. Ultimately, Brett shows that where there is evidence of waiver before the court, a s 5 approach is not fit for purpose.

\section{Failure to Consider a Better Approach}

The Court of Appeal's decision in Brett demonstrated that considering waiver under s 5 - or a "s 5 approach" - is not fit for purpose. This article submits that a better approach would have been to consider Mr Brett's waiver earlier, when determining whether his right had been breached. Introduced above, a "prima facie breach approach" scrutinises the waiver at the first stage of the NZBORA framework, as opposed to at the second stage (under s 5). On this approach, if a court is satisfied that a waiver was valid - ie a right-holder's act of relinquishing a right was informed, clear and voluntary - it will deem that there is no interference with the right. Without a prima facie breach to rely upon, the right-holder's claim under the NZBORA will automatically fail.

The advantage of adopting a prima facie breach approach to waiver, overlooked by the Court of Appeal in Brett when it elected a s 5 approach, is that it is congruent with the theoretical basis of waiver. As a result, this alternative approach directs a court's analysis to the matters most pertinent when the issue of waiver is before a court, unlike the s 5 approach which misdirected the Court's analysis in Brett. In doing so, the prima facie breach approach equips a court to properly scrutinise a waiver. Unlike the Court's s 5 approach in Brett which was misdirected and thus led to gaps in the Court's analysis, the prima facie breach approach would have allowed the Court to fully interrogate Mr Brett's waiver. As a result, it is submitted, perhaps the Court would not have reached the same conclusion that Mr Brett had waived his right to freedom of expression.

\section{Congruence with conceptual foundations of waiver}

What makes the prima facie breach approach the most fit for purpose when dealing with a waiver is its congruence with waiver's theoretical underpinnings. This article submits that it was a lack of alignment with the conceptual basis of waiver which led the Court of Appeal's s 5 approach in Brett

119 At [38].

120 At [40]. 
to be so futile. Any approach to waiver which ignores these conceptual underpinnings will be inevitably misdirected, and accordingly not fit for purpose.

As submitted in earlier, the conceptual basis of waiver is autonomy. If all rights presuppose that individuals possess the autonomy to choose how a right will be exercised, that same respect for autonomy should extend to a right-holder's choice to waive that right. ${ }^{121}$

In order to give full effect to the autonomy interest inherent in waiver, it is not sufficient that a court merely recognise this act of relinquishment. Rather, that court must also find that because the right-holder has waived the right, there can be no possible interference with it by the s 3 body. Hogg uses the example of an individual waiving their right to a lawyer: if this right is waived, then the police are free to question the accused without infringing that right. ${ }^{122}$ This is because in exercising his or her autonomy to relinquish a given right, the right-holder has thereby given up the protection that it affords. ${ }^{123}$

Nevertheless, the s 5 approach, adopted by the Court in Brett, disregarded this conceptual basis of waiver. While the Court gave effect to the notion of autonomy by recognising Mr Brett's waiver in the first place, it failed to extend this recognition when it went on to analyse the waiver. By assuming that even if Mr Brett had waived his right, it had still been interfered with by the LVVTA and required justification under s 5, the Court disregarded the personal autonomy inherent in the waiver: that $\mathrm{Mr}$ Brett wished to relinquish any protection afforded by that right. ${ }^{124}$

The better view, conceptually congruent with waiver's theoretical grounding in autonomy, would have been to adopt the prima facie breach approach. There, if a court establishes that a right-holder's waiver was valid, there is no interference with the right and the right-holder's claim under the NZBORA automatically fails. Unlike the Court of Appeal's approach, the claim does not proceed to s 5 where the reasonableness, proportionality and justification of the interference is discussed. There is no discussion of Oakes and its inquiries, because the approach acknowledges that these are no longer the pertinent issues. The nature of the NZBORA claim has changed and any attention given to matters of justification, above and beyond whether the waiver was valid, will misdirect a court. It is both conceptually incoherent - as well as dismissive of a right-holder's exercise of autonomy - to say that, once an individual has relinquished their right, their right has been "interfered" with, requiring justification. The right-holder has simply lost the ability to rely on its protection. ${ }^{125}$ Accordingly, if a

121 Berg, above n 57, at 289. See also Harker, above n 62, at 161; Aall, above n 55, at 301; and Hogg, above n 62 , at $[37.3(\mathrm{~b})]$.

122 Hogg, above n 62, at [37.3(a)].

123 Aall, above n 55, at 312; and Harker, above n 62, at 164.

124 Compare Cropp, above n 84, at [21]. See also Aall, above n 55, at 366.

125 Johnson $v$ Zerbst, above 85, at 464. See also Young, above n 56, at 50. 
court is to give full effect to the exercise of autonomy manifested in a waiver, the prima facie breach approach is the only one open.

\section{More rigorous scrutiny given to waiver}

Given that waivers have the power to deprive an individual of a protected right, ${ }^{126}$ a court ought to rigorously scrutinise any waiver that comes before it. However as a result of its misdirected s 5 approach, the Court of Appeal failed to adequately scrutinise Mr Brett's waiver. While the Court did weigh up whether the waiver was voluntarily entered into and for Mr Brett's benefit, it did not apply any robust test for determining the waiver's validity, nor did it properly subject it to a s 5 assessment as it had proposed to do.

Had the Court employed the informed, clear and voluntary standard under the prima facie breach approach, proper scrutiny would have been given to Mr Brett's waiver. This article seeks to demonstrate what this rigorous analysis of Mr Brett's waiver would have looked like under this approach. In particular it highlights how the Court ignored a critical component of the waiver standard - whether Mr Brett's waiver was informed - in the face of evidence that he entered into the agreement without legal advice. If the Court had considered all of the relevant evidence, it is submitted that it may have reached a different conclusion on Mr Brett's claim.

The waiver standard ensures that before a waiver is declared effective by a court, "adequate procedural guarantees" are given to the right-holder, "whose choice must not be coerced, must be fully informed, and must be unequivocally expressed". ${ }^{127}$ Importantly, this standard displaces the role of s 5: rigour is provided through the validity assessment alone. This runs counter to the perception that $\mathrm{s}$ 5 is the cornerstone of scrutiny, ${ }^{128}$ but still provides for robust and careful analysis, just on different issues than a conventional s 5 assessment. The waiver standard acknowledges that when there is an issue of waiver before a court, the nature of the claim changes and matters of justification are no longer the pertinent issues. Instead, the focus shifts from whether the s 3 body's interference was justified, to whether the right-holder's act of contracting out was valid. A burden is thereby placed on the s 3 body to establish that the waiver was sufficiently informed, unequivocal and voluntary. ${ }^{129}$

As outlined, there are three elements to the waiver standard: that the waiver was informed, unequivocal and voluntary. ${ }^{130}$ Crucially, the first requirement, that the waiver was informed, was not

126 Paciocco, above n 1, at 381 .

127 Olivier De Schutter "Waiver of Rights and State Paternalism under the European Convention on Human Rights" (2000) 51 NILQ 481 at 508

128 See Butler and Butler, above n 33, at [6.6.6], proponents of the "ad hoc balancing" approach.

129 See Police v Kohler, above n 82; and Lisiate $v$ R, above n 80.

130 Lisiate $v$ R, above n 80, at [15]; and Police v Kohler, above n 80, at 133. See also Hogg, above n 62, at $[37.3(\mathrm{a})]$. 
applied by the Court of Appeal. "Informed" requires that the right-holder not only fully understands the right that they allegedly waived, ${ }^{131}$ but also that they have a full understanding of the implications of the waiver. ${ }^{132}$ When the waiver arises in the course of legal proceedings, whether the right-holder was adequately informed will often depend on whether they have legal representation because special knowledge of the area is usually presupposed. ${ }^{133}$

Palmer $\mathrm{J}$ in the High Court observed that Mr Brett had waived his right to freedom of expression without legal advice. ${ }^{134}$ However the Court of Appeal did not mention this finding in determining that Mr Brett's waiver was effective. This raises an important question: whether a lack of legal advice would have rendered Mr Brett's waiver invalid. While the absence of legal advice may suggest a waiver was uninformed, this article submits that, if a court is nonetheless satisfied that the right-holder sufficiently understood the right waived and the consequences of waiving it, this presumption ought to be rebutted.

Without a full picture of the circumstances in which Mr Brett allegedly waived his right, a definitive conclusion cannot be reached on whether, without legal advice, the waiver was sufficiently informed. However, without intending to be exhaustive, this article suggests a number of inquiries that a court should make, if this question was before it. How these matters are weighed and balanced will inevitably depend on a court's view of the evidence before it.

First, a court ought to consider the complexity of the waiver. Arguably, if the contents of a rightholder's waiver were straightforward, this may suggest that a decision to waive the right without legal advice was informed. It could be argued that Mr Brett's waiver was straightforward. Indeed, as Palmer J did in the High Court, the agreement could be succinctly summed up as: "the LVVTA agree[ing] not to sue Mr Brett for defamation in return for Mr Brett removing material from his website and not posting more". ${ }^{135}$ However from another point of view, Mr Brett's obligations under cl 5 of the agreement were complex. ${ }^{136}$ Indeed, sub-cl (a)(ii) required Mr Brett to remove statements from his website that "are, or may be perceived to be, in any way defamatory towards LVVTA", an obligation that would require a high comprehension of defamation law to attain compliance. ${ }^{137}$ Thus, maybe the

131 Butler and Butler, above n 33, at [20.11.34].

$132 R$ v Clarkson [1986] 1 SCR 383 at 390.

133 De Schutter, above n 127, at 491.

134 Brett (HC), above n 8, at [106].

135 At [19].

136 See Part II(B) for the full text of this clause.

137 Settlement Agreement, cl 5, as quoted in Brett (CA), above n 3, at [11]. 
waiver was too complex for Mr Brett to understand what he consented to without legal advice, suggesting that his waiver was uninformed. ${ }^{138}$

Another factor that may be relevant to whether the waiver was informed is the right-holder's education and legal understanding. Even if a court determines that the waiver was complex, if the right-holder's level of education or legal understanding is high, this may suggest that their waiver was sufficiently informed. For instance, whether Mr Brett received legal training in the past, or had researched the legal issues online, could be matters that a court should inquire into. On the other hand, if $\mathrm{Mr}$ Brett was poorly educated, this may suggest his waiver was not informed. Indeed, in the case of DH $v$ The Czech Republic, the European Court of Human Rights held that the appellant's waiver of their art 14 right to be free from discrimination was not informed. ${ }^{139}$ Without legal advice, the appellants who were poorly educated, were unable to weigh up "all the aspects of the situation and the consequences of giving their consent". ${ }^{140}$

Finally in relation to the requirement to be informed, a court should inquire into any other relevant circumstantial evidence pertaining to when the waiver was entered into. While there is no suggestion that $\mathrm{Mr}$ Brett had any particular intellectual disabilities ${ }^{141}$ or was intoxicated at the time the agreement was signed, ${ }^{142}$ these kinds of matters could bring into question whether his waiver was informed. Moreover, evidence of correspondence between Mr Brett and the LVVTA's counsel may provide insight into whether Mr Brett understood what he was waiving. Whether Mr Brett had expressed confusion or hesitation about the agreement, for instance, could be relevant.

These kinds of factual inquiries would have helped the Court of Appeal to determine whether Mr Brett's waiver was adequately informed without the benefit of legal advice. Although not based on a complete picture of all of the evidence, this article submits that if this element had been considered by the Court, it may have found that Mr Brett's waiver was uninformed. Waivers are complex legal matters and without the benefit of legal advice or legal training, Mr Brett would have arguably lacked sufficient information to make an informed and appropriate decision about it. ${ }^{143}$

138 Aall, above n 55, at 354; and Pfeifer v Austria (1992) Series A no 227. See also Thompson v The United Kingdom (2005) 40 EHRR 11 (ECHR) at [44] (where the right-holder "was a layman not in a position to evaluate his legal position").

139 DH v The Czech Republic [2007] 4 ECHR 241 (Grand Chamber).

140 At 245

141 See Ballantyne v $R$ [2017] NZCA 363 at [31].

142 See $R v$ Clarkson, above n 132, at 390; and Edward L Rubin "Toward A General Theory of Waiver" (1981) 28 UCLA L Rev 478 at 495.

143 Butler and Butler, above n 33, at [20.7.61]. See also $R v$ Smith [1991] 1 SCR 714 at [28] per McLachlin J, as cited in $R v$ Tawhiti [1993] 3 NZLR 594 (HC) at 599. 
The second requirement for a valid waiver is that it was unequivocal. ${ }^{144}$ This, too, was not considered by the Court in Brett. A right-holder must have made a sufficiently "'clear and unequivocal' indication that waiver is intended". ${ }^{45}$ For this reason, the Court of Appeal in Police v Kohler held that "a valid waiver cannot be implied from silence". ${ }^{146}$ If the Court had applied this element of the standard, it would likely have found the waiver to be sufficiently unequivocal. Indeed, the settlement agreement explicitly and unequivocally set out Mr Brett's waiver. Given that this element is uncontentious on the facts it is arguably understandable that the Court did not consider it. Nevertheless, in order to give Mr Brett's waiver the necessary scrutiny, all three elements of the validity standard ought to have been explicitly set out and analysed, whether or not a particular element was obviously satisfied on the facts.

The final requirement is that the waiver was voluntary. ${ }^{147}$ This was the only element of the waiver standard considered by the Court in Brett. The voluntary requirement ensures that a waiver was "the product of an essentially free and unconstrained choice by its maker". ${ }^{148}$ As touched upon the Court, if the agreement would be otherwise illegal at law, for example because it was coerced, ${ }^{149}$ compelled $^{150}$ or obtained under conditions amounting to duress, ${ }^{151}$ this may suggest that the contractual waiver was involuntary. Nevertheless, no concerns were raised by the Court about the voluntariness of Mr Brett's waiver. Indeed, the Court noted that there was no suggestion that the agreement was illegal other than in terms of the NZBORA. ${ }^{152}$

Notwithstanding the Court of Appeal's finding as to voluntariness, one fact ignored by the Court, but noted by Palmer J in the High Court, was that Mr Brett had abrogated his right under the threat of a defamation suit. While Palmer $\mathrm{J}$ did not refer to a lack of voluntariness in his decision, he appeared to attach importance to the impending legal action when he concluded that he would not have upheld

144 Lisiate v R, above n 80, at [15]; and Police v Kohler, above n 80, at 133. See also Hogg, above n 62, at [37.3(a)].

145 Rubin, above n 142, at 516.

146 Police v Kohler, above n 82, at 133.

147 Lisiate $v$ R, above n 80, at [15]; and Police v Kohler, above n 80, at 133. See also Hogg, above n 62, at [37.3(a)].

148 Culombe v Connecticut 367 US 568 (1961) at 602, as quoted in Rubin, above n 142, at 492, n 287.

149 Young, above n 56, at 58.

150 Rubin, above n 142, at 492.

151 De Schutter, above n 127, at 489.

152 Brett (CA), above n 3, at [40]. 
the waiver, had he thought the right to freedom of expression could be waived. ${ }^{153}$ Indeed, one scholar has suggested that legal action may constitute an improper threat. ${ }^{154}$

The Court of Appeal's assessment of voluntariness was convincing. In the absence of any evidence that Mr Brett's consent was extorted, coerced or compelled, the mere fact that the agreement was entered into under the threat of legal action ought not to render it invalid. To find otherwise would be to threaten the basis for the many settlement agreements entered into every day. As discussed above, there is a strong public interest in upholding such compromises, not only in terms of freeing up court resources, but also in mitigating the risks for private litigants. ${ }^{155}$

By setting out and analysing the three elements of the waiver standard, this article has demonstrated the kind of scrutiny to which Mr Brett's waiver ought to have been subjected to. Importantly, it has highlighted that as a result of the Court of Appeal's flawed analysis, it left key facts, such as Mr Brett's lack of legal advice, untouched. Ultimately, such gaps in the Court's analysis demonstrate the importance of subjecting waivers to proper scrutiny. Waivers express a right-holder's choice to surrender a given right and it is critical that the courts ensure that this is in fact their free choice. If a waiver of an individual's right to freedom of expression can be recognised without consideration given to whether it was sufficiently informed, the protections afforded by the NZBORA risk being undermined.

\section{CONCLUSION}

DM Paciocco observed, rightly, that "persons ought not to be deprived easily of fundamental rights and freedoms". ${ }^{156}$ This article has argued that whilst a decision to deprive oneself of one's right to freedom of expression should be recognised by the courts, this recognition should not be given easily. Courts must ensure that the waiver reflects the right-holder's free choice or otherwise s 3 bodies will be allowed to abandon their constitutional commitments too easily.

In Brett, the Court of Appeal failed to give effect to this notion. This article has submitted that, while it was right to find that $\mathrm{Mr}$ Brett could waive his right to freedom of expression, the Court's s 5 approach failed to subject his waiver to proper scrutiny. If the Court had taken a different approach it may not have concluded that the waiver was valid. Unfortunately, Mr Brett may in fact have been deprived too easily of a fundamental right.

153 Brett (HC), above n 8, at [106].

154 Berg, above n 57, at 311.

155 Brett (CA), above n 3, at [38].

156 Paciocco, above n 1, at 381. 